\title{
Note
}

\section{Compatibility and Interconnection Pricing in the Airline Industry: A Proposal for Reform}

\author{
Bradley H. Weidenhammer
}

CONTENTS

INTRODUCTION 407

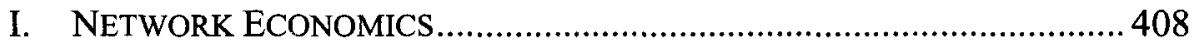

A. Direct and Indirect Network Effects ...........................................409

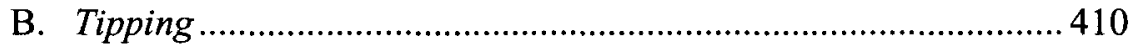

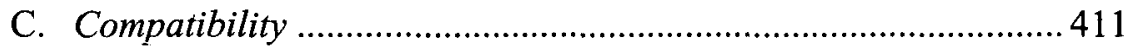

1. The Economics of Compatibility Choices ..............................412

2. Interconnection Pricing...................................................... 413

II. NETWORK EFFECTS, COMPATIBILITY, AND ANTITRUST ANALYSIS... 415

III. COMPETITION AND COMPATIBILITY AMONG Airline NeTwORKS ... 421

A. The History of Airline Competition ............................................. 421

B. Network-Compatibility Theory and the Airline Industry .............427

1. Modeling Compatibility and Interconnection Pricing Among Airline Networks

2. Observing Compatibility and Interconnection Pricing in the Airline Market 
IV. ASSESSING EFFICIENCY, PROPOSING REFORM ............................... 433

A. Compatibility Through Regulation ............................................ 434

B. Welfare Analysis ................................................................... 436

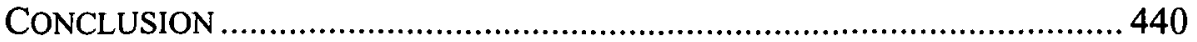




\section{INTRODUCTION}

Since the deregulation of the airline industry in the late 1970 s, the behavior of firms in the industry has often baffled analysts and stymied prognosticators. In the years preceding and immediately following deregulation, scholars theorized that the deregulated airline industry would approximate perfect competition.' Scholars reasoned that because the airline industry did not appear to manifest significant economies of scale, firms would be able to enter the market at a relatively small scale and still attain competitive costs and discipline large firms' pricing. ${ }^{2}$ Moreover, because existing firms had bloated costs and suboptimal route structures, new entrants were expected to achieve drastically lower costs and to unseat incumbents quickly. ${ }^{3}$

Yet none of these predictions has come to pass. Firms existing before regulation (so-called "legacy firms") did not disappear. Instead, they survived and grew to dominate the industry without bringing their costs down near the level of entrant firms. The anticipated contestability of the airline market-the ability of firms to engage in hit-and-run market entry wherever supracompetitive rates are being charged-never materialized. In addition, the incumbents soon reorganized their route plans into hub-andspoke networks. Airlines turned to hubbing ostensibly as a cost-saving measure, though scholars have since shown that hubbing is also an effective entry-deterrence strategy. ${ }^{4}$

This Note suggests that network-compatibility theory can explain some of the perplexing conduct we observe in the airline market. In particular, I argue that competition in the airline industry functions at a suboptimal level, in part because systemic incompatibilities between airlines permit competition only at the network or full-itinerary level, foreclosing competition at the component-flight level. Logistical difficulties involved in connecting from one airline to another have thwarted compatibility among airline networks. Furthermore, the dominant airline networks have used pricing policy to anticompetitive effect, setting high interconnection fees that reduce consumer welfare.

Scholars have paid little attention to the effects of incompatibility on competition in the airline industry, despite the well-established correlation

1. See, e.g., Elizabeth E. Bailey \& William J. Baumol, Deregulation and the Theory of Contestable Markets, 1 YALE J. ON REG. 111 (1984); Theodore E. Keeler, Airline Regulation and Market Performance, 3 BELL J. ECON. \& MGMT. SCI. 399 (1972).

2. See, e.g., RICHARD E. CAVES, AIR TRANSPORT AND ITS REgUlatORS: AN INDUSTRY STUDY (1962).

3. See, e.g., Keeler, supra note 1; Michael E. Levine, Financial Implications of Regulatory Change in the Airline Industry, 49 S. CAL. L. REV. 645, 655-57 (1976).

4. See infra notes 111-118 and accompanying text. 
between network incompatibility and the creation of market power by a dominant network. ${ }^{5}$ Moreover, where incompatibility exists among competing networks, free entry may not erode a dominant network's market power. ${ }^{6}$ Hence, scholars taking the orthodox view that free entry assures optimal market performance fail to account adequately for the network aspect of the airline industry.

This Note attempts to remedy this gap in the literature by using network-compatibility and interconnection-pricing theory to analyze firm behavior in the airline industry and to propose a corrective regulatory regime. Part I introduces relevant elements of network economic theory. Part II examines important antitrust cases to construct a framework for analyzing the welfare effects of compatibility decisions. Part III then discusses network effects in the airline industry, surveys the history of airline competition since deregulation, and demonstrates the ability of network-compatibility and interconnection-pricing theory to describe and account for airline behavior. Part IV employs network theory to formulate a regulatory solution to the market failures identified in Part III and discusses the costs and benefits of the proposed regulation.

\section{NETWORK ECONOMICS}

Economists have long recognized that the consumption value of some products depends on the number of other consumers who use those products. For example, a telephone has value only as a paperweight unless there are other telephone users with whom one can communicate. Similarly, a car is more valuable if repair shops are plentiful, and the number of repair shops depends on the existence of other car users within a reasonable proximity. As the number of people who speak English increases, English language skills become more valuable. ${ }^{7}$ Economists use the term "network effect" to describe the benefit consumers experience as the result of others" consumption of the same product. ${ }^{8}$

5. See NiChOlas ECONOMIDES, COMPETITION POLICY IN NETWORK INDUSTRIES: AN INTRODUCTION 15 (Stern Sch. of Bus., NYU, Working Paper No. EC-03-09, 2003), availabie at http://www.stern.nyu.edu/networks/Competition_Policy.pdf.

6. See id.

7. See Joseph Farrell \& Garth Saloner, Installed Base and Compatibility: Innovation, Product Preannouncements, and Predation, 76 AM. ECON. REV. 940, 940 (1986) (noting that standardization of language creates "demand-side economies of scale ... [, i.e.,] benefits to doing what others do").

8. See, e.g., Nicholas Economides, The Economics of Networks, 14 INT'L J. INDUS. ORG. 673, 691 (1996). Michael Katz and Carl Shapiro use the term "network externality" to describe this phenomenon. Michael L. Katz \& Carl Shapiro, Network Externalities, Competition, and Compatibility, 75 AM. ECON. REV. 424, 424 (1985). 


\section{A. Direct and Indirect Network Effects}

A network consists of two or more interconnected nodes. Connections between the nodes may be physical, as in the case of telecom or highway networks, or based upon common standards, such as language (for example, Portuguese or the software language $\mathrm{C}++$ ) or design (for example, electrical outlet configurations). Analytically, however, the means of connectivity is less important than the type of consumption benefits the network creates. Since Michael Katz and Carl Shapiro first suggested the distinction, economists have generally distinguished between direct and indirect network benefits. ${ }^{9}$ Though the distinction is not always easily made,${ }^{10}$ direct network benefits generally exist where the good being consumed is connectivity itself. ${ }^{11}$ A paradigmatic example of a direct network benefit is the benefit realized when a communication network is expanded: Each member realizes a direct benefit in the form of expanded communication opportunities. $^{12}$

Indirect network benefits are realized by consumers of goods that are not instruments of connectivity but that increase in value as consumption of the product increases. ${ }^{13}$ For example, a Ford Taurus is valuable regardless of whether anyone else drives a Taurus, but economies of scale dictate that complementary goods (such as repair shops and replacement parts) will be more widely available if the pool of Taurus drivers is larger. Thus, a Taurus owner experiences positive consumption effects indirectly-through an increasing variety and availability of complementary goods.

Consumers joining a network create an externality insofar as they create benefits to other users of the network that they themselves do not internalize. ${ }^{14}$ As a result, networks tend to be smaller than optimal because marginal consumers do not sufficiently value their participation in the network and may fail to join even when total (internal and external) benefits

9. See Katz \& Shapiro, supra note 8 , at 424 . Scholars have variously referred to networks that produce direct effects as "communications networks," see, e.g., Michael L. Katz \& Carl Shapiro, Systems Competition and Network Effects, J. ECON. PersP., Spring 1994, at 93, 96, or "actual networks," see, e.g., Mark A. Lemley \& David McGowan, Legal Implications of Network Economic Effects, 86 CAL. L. REV. 479, 488 (1998). Likewise, some scholars have adopted the term "virtual networks" to describe networks that produce indirect effects. See, e.g., ECONOMIDES, supra note 5, at 5 . I retain the direct/indirect terminology because I think it more accurately describes the difference between the two types of network effects.

10. See Lemley \& McGowan, supra note 9, at 494 ("[N]etworks need be neither entirely 'actual' nor entirely 'virtual."').

11. See Katz \& Shapiro, supra note 8, at 424.

12. See id.

13. An easy way to think about the direct/indirect distinction is to ask whether the good would have value if consumed in isolation. A fax machine or a telephone is virtually worthless without other users, while an automobile retains its essential value in isolation.

14. See, e.g., Economides, supra note 8, at 679. 
outweigh total cost. ${ }^{15}$ Where a network is proprietary, however, the owner is able to internalize all network benefits by subsidizing marginal consumers and extracting the additional network value from existing members. ${ }^{16}$

Though a debate is ongoing as to what constitutes a network benefit versus a network externality, ${ }^{17}$ it is sufficient for our purposes to use the terms "network benefit" to denote the portion of a good's value that is attributable to network size and "network externality" to denote the difference between the social marginal benefits and the private marginal benefits of an additional consumer joining a network.

\section{B. Tipping}

In an industry that exhibits network effects, the convergence of consumers to a single standard or network will maximize network effects. ${ }^{18}$ Thus, in industries in which multiple incompatible networks compete (assuming uniform quality across competing networks), even a small size advantage will make one network more desirable than the others. ${ }^{19}$ The emergence of a size leader produces a demand-side feedback loop where each new adopter increases the relative value of the network, thus increasing demand for the network. This, in turn, further increases the relative value of the network, and so on, producing a dominant firm. ${ }^{20}$ This phenomenon is referred to as "tipping."

Once a firm attains a dominant size, the network benefits realized by its consumers vastly outstrip the network benefits other firms in the market

15. See, e.g., Katz \& Shapiro, supra note 9, at 96 ("Since social marginal benefits exceed private marginal benefits - that is, since there are adoption externalities-the equilibrium network size is smaller than the socially optimal network size, and the perfectly competitive equilibrium is not efficient.").

16. Katz and Shapiro argue that the phenomenon of network externalities is essentially an investment problem. See Katz \& Shapiro, supra note 9, at 101. In the absence of transaction costs, we would expect the existing members of nonproprietary networks to coordinate and subsidize marginal consumers. However, the cost of such coordination makes it likely that only the network owner will be able to internalize marginal consumers' adoption externalities efficiently because it is able, through pricing strategies, to subsidize new members easily and extract the additional network value from existing members.

17. See, e.g., Lemley \& McGowan, supra note 9, at 482-83; S.J. Liebowitz \& Stephen E. Margolis, Are Network Externalities a New Source of Market Failure?, in 17 RESEARCH IN LAW AND ECONOMICS 1 (Richard O. Zerbe, Jr. \& William Kovacic eds., 1995), available at http://www.utdallas.edu/ liebowit/netwextn.html.

18. This is true regardless of which standard is chosen, even if one standard is markedly better than the others. Of course, overall welfare will only be maximized where all consumers converge on the optimal standard. See STAN J. Liebowitz \& STEPHEN E. MARgOLIS, WinNERS, LOSERS \& MICROSOFT: COMPETITION AND ANTITRUST IN HIGH TECHNOLOGY 92 (rev. ed. 2001).

19. See ECONOMIDES, supra note 5, at 21 (arguing that incompatibility is a necessary condition for tipping to occur).

20. See Stanley Besen \& Joseph Farrell, Choosing How To Compete: Strategies and Tactics in Standardization, J. ECON. PERSP., Spring 1994, at 117, 122. 
may offer. ${ }^{21}$ While this does not foreclose entry completely, it provides the dominant firm with a competitive advantage that shields it somewhat from direct competition over productive efficiency or product quality. ${ }^{22}$ For an entrant network to draw customers away from a dominant network, the entrant must offer substantive benefits that exceed the value of the dominant network's substantive benefits plus its network benefits. ${ }^{23}$ Thus, where rival, incompatible networks compete, and where one network has a first-mover advantage, the dominant network may preserve its market share over time, in spite of an entrant's superior productive efficiencies.

\section{Compatibility}

Compatibility is perhaps the most important concept in understanding network industries. Total compatibility exists when two components are combinable and function together without extra costs. Partial compatibility is also possible. For example, American electrical plugs are compatible with outlets in the United Kingdom, but an adapter is required. The compatibility of any two components falls along a continuum stretching from total compatibility, when two components function together without additional cost, to total incompatibility, when the cost of achieving compatibility outweighs the benefit.

When two systems exhibiting network effects are compatible, an aggregate network is formed, composed of the total membership of all compatible systems. ${ }^{24}$ For instance, land-line telephones and citizen-band (CB) radios are incompatible communication networks; therefore, the value of the telephone network versus that of the CB-radio network is a function of the size of each respective network. An increase in the size of one network does not increase the value of the other. However, land-line telephones and wireless telephones are compatible networks, so the value of each is a function of the size of the network comprising both land-line and wireless users. Thus, the network benefit of adding an additional wireless user redounds to users of land-line and wireless telephones alike.

Economic research suggests that when systems are compatible, rival networks stop competing to reach the tipping point and instead compete on

21. See id.

22. Probably the most familiar example of this phenomenon in the popular imagination is the competition between rival videocassette formats. According to the conventional narrative, the VHS format was technologically inferior to the Beta format. But because the VHS format captured early market share and network effects were important in the market, VHS came to dominate the market, locking consumers in to an inferior standard. As Stan Liebowitz and Stephen Margolis demonstrate, however, other factors may have been behind the dominance of the VHS format. See S.J. Liebowitz \& Stephen E. Margolis, Path Dependence, Lock-In, and History, 11 J.L. ECON. \& ORG. 205, 208-09 (1995).

23. See Besen \& Farrell, supra note 20, at 122.

24. See Katz \& Shapiro, supra note 9, at 109. 
more familiar terms such as price, quality, or reputation. ${ }^{25}$ In other words, rivals compete within the market rather than for the market. Achieving compatibility among systems, therefore, maximizes total network value by aggregating all members in a single network and promotes efficiency by supplanting competition over proprietary-network size with competition on non-network product features. As a leading economist in the field has concluded, "[T]he key to increasing social welfare is to move to compatibility.... [A]ssuming that innovation and product availability would not be reduced, the best of all worlds is to have public standards and full compatibility."26

\section{The Economics of Compatibility Choices}

Firms make compatibility decisions strategically. ${ }^{27}$ Those firms that have a competitive advantage under incompatibility will prefer not to standardize ${ }^{28}$ and may be expected to resist any effort that moves toward compatibility. ${ }^{29}$ As a general rule, a firm's preference for compatibility is a function of the difference between the firm's own-product demand and expected demand for a hybrid product ${ }^{30}$ under compatibility. ${ }^{31} \mathrm{Katz}$ and Shapiro point out that "if one firm has a distinctly superior overall package, ... that firm is likely to prefer incompatibility. ${ }^{, 32}$ On the other

25. See, e.g., Katz \& Shapiro, supra note 9, at 110.

26. ECONOMIDES, supra note 5, at 21.

27. See, e.g., Katz \& Shapiro, supra note 8 , at 425.

28. See id. at 434-39 (offering a useful model demonstrating the conditions under which a firm may prefer incompatibility even though consumer welfare is maximized by compatibility).

29. For example, in the 1980 s, when Nintendo had an eighty percent share of the home videogame market, see Atari Games Corp. v. Nintendo of Am., 897 F.2d 1572, 1574 (Fed. Cir. 1990), it engineered its gaming systems to function only with Nintendo games and would only license its technology to outside game developers at a rate of ten games per developer. Atari engineered an adapter to overcome this incompatibility and also sued Nintendo to enjoin its restrictive licensing practices as violations of antitrust laws. Nintendo brought a cross-claim against Atari for infringing Nintendo's copyright when developing the adapter. See Atari Games Corp. v. Nintendo of Am., Nos. C-88-4805-FMS et al., 1991 WL 57304, at *1 (N.D. Cal. Apr. 11, 1991) (enjoining Atari's copyright infringement and denying Atari's petition for relief from Nintendo's alleged antitrust violations), aff'd, 975 F.2d 832 (Fed. Cir. 1992).

30. A hybrid is a good comprising compatible components from two or more firms. See Economides, supra note 8 , at 687 .

31. See id. (demonstrating that a firm whose own-product demand is less than its share of a hybrid product under compatibility will desire compatibility).

32. Katz \& Shapiro, supra note 9, at 110. The authors further note that "since systems competition is prone to tipping, there are likely to be strong winners and strong losers under incompatibility. Therefore, if a firm is confident that it will be the winner, that firm will tend to oppose compatibility." Id. at 111 . Applying this logic to the airline industry, we do not see tipping per se, because consumers do not experience high switching costs or lock-in, but as Part III demonstrates, network size is nevertheless important under the current market structure. Therefore, those airlines that currently have a size advantage likely will prefer incompatibility and can be expected to expend resources to preserve it (and with it, their competitive advantage). See also Economides, supra note 8, at 687. 
hand, "if each firm has a distinctly superior component, both firms may prefer compatibility and may spend resources to achieve it.","33

Thus, competition among networks or standards may arrive at a suboptimal equilibrium at which, although consumer welfare would have been maximized under compatibility, a dominant network firm that makes standardization and compatibility decisions without taking the social costs and benefits into account prefers incompatibility. ${ }^{34}$ The potential for suboptimality in competition among networks is an important consideration for policymakers and judges who create and apply competition law based on the general axiom that unregulated competition maximizes welfare. ${ }^{35}$

\section{Interconnection Pricing}

Even where rival networks are technologically compatible or semicompatible, in certain circumstances a dominant network may employ pricing strategies that make inter-network combinations prohibitively expensive and insulate it from competition from new entrants. Where network consumers may connect across rival networks--that is, combine components of each to create a single good-the network with a superior overall package will seek to foreclose competition at the component level. ${ }^{36}$ Technological incompatibility is one way to achieve that goal; introducing discriminatory inter-network pricing is another.

Nicholas Economides has modeled the pricing behavior of firms in a telecommunications market dominated by an incumbent carrier. The model works as follows: Assume two telecom networks, $A$ and $B$, where network size $n_{a}>n_{b}$, and consumers cannot be members of both networks simultaneously. Consumers may make both intra-network ${ }^{37}$ and internetwork ${ }^{38}$ calls, and only the party placing the call is charged. All calls are routed through a single hub, $H$. Each spoke represents a subscriber to either $A$ or $B$. Each network sets the price of its internal calls (both caller and recipient subscribe to the same network) as well as the origination (caller to hub) and termination (hub to recipient) components of inter-network calls. ${ }^{39}$

33. Katz \& Shapiro, supra note 9, at 110 (emphasis added). Making the two superior components compatible increases the total value of the combined good and shifts the demand curve outward to the benefit of both firms.

34. See supra note 29.

35. See, e.g., Brooke Group Ltd. v. Brown \& Williamson Tobacco Corp., 509 U.S. 209, 254 (1993) (noting the axiom that "antitrust laws were passed for the protection of competition" (emphasis and internal quotation marks omitted)).

36. See supra note 32 and accompanying text.

37. That is, terminating on the same network.

38. That is, terminating on the rival network.

39. See Nicholas Economides et al., Regulatory Pricing Policies To Neutralize Network Dominance, 5 INDUS. \& CORP. CHANGE 1013, 1016-17 (1996). 


\section{FIGURE 1. A TELECOM NETWORK}

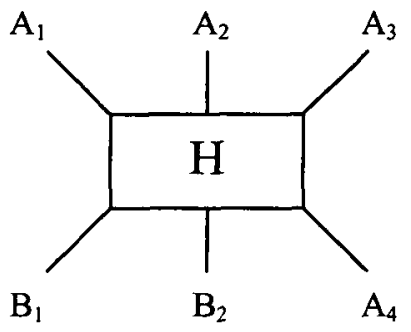

Economides finds that in such a market, network $A$ has an incentive to "price squeeze" rival entrant $B$ by charging $B$ 's members more for access to its network components than the implicit price it charges its own members. ${ }^{40}$ Assume, for example, the price of a call from $A_{1}$ to $A_{2}$ is $\$ 2$, representing an implicit charge of $\$ 1$ for component $A_{I}-H$ and $\$ 1$ for component $H-A_{2}$. The price of internal calls for network $B$ are the same. For call $B_{1}-H-A_{2}, A$ can "price squeeze" $B$ by charging $\$ 2$ for component $H-A_{2}$, raising the cost of the inter-network call to $\$ 3$. As a result of this discriminatory interconnection pricing, intra-network calls are less expensive than inter-network calls. This interconnection pricing strategy may effectively create a barrier to inter-network connections. ${ }^{41}$ Under such conditions, $A$ 's larger size makes it more valuable because it offers a greater number of individuals whom one may call at the lower, internal rate. This tends to concentrate the market in much the same way a strong network benefit would. ${ }^{42}$ In the extreme, the dominant carrier may refuse to interconnect with competitors' networks on any terms, excluding competitors from a large segment of the market and making entry unlikely. ${ }^{43}$

Economides demonstrates that network dominance through discriminatory interconnection pricing can be eliminated by imposing an "imputation rule" on the industry, whereby each network must sell originating or terminating components of inter-network calls at the same price it implicitly charges when selling the components as part of intra-

40. Id. at 1019.

41. Economides and his coauthors refer to this phenomenon as a "pecuniary externality." Id. at 1018 .

42. See id. at 1022 ("[C]ompetition between networks for subscribers may 'tip' the industry toward monopoly because of price-induced demand-side scale economies.").

43. See id. at 1014. 
network calls. ${ }^{44}$ Thus, taking the example in Figure 1 , if the price of call $A_{I^{-}}$ $H-A_{2}$ is $\$ 2$, the sum of the implicit internal price for each component will equal $\$ 2$. Assuming that the implicit internal price for $H-A_{2}$ is $\$ 1$, then under the imputation rule, members of $B$ may be charged no more than $\$ 1$ for $H-A_{2}$. Imputation results in "redistribut[ion] [of] profits from the dominant network to its rival and raises welfare of the rival's subscribers, encouraging entry by new carriers to the benefit of all subscribers." 45

\section{NETWORK EFFECTS, COMPATIBILITY, AND ANTITRUST ANALYSIS}

As the discussion above indicates, incompatibilities among rivals may undermine competition in network industries. This raises a concern over the extent to which a network firm's decision to create or preserve incompatibility is improperly exclusionary and therefore an appropriate subject of antitrust sanction or regulation. ${ }^{46}$ This Part discusses two important antitrust cases that together suggest a useful framework for analyzing the welfare effects of compatibility decisions. Of course, identifying a practice that reduces consumer welfare is a far cry from identifying a violation of antitrust laws, and this Part is concerned only with the former, not the latter. The decisions are used as a means to identify the proper analytical approach.

Exclusion is a tricky concept in antitrust. ${ }^{47}$ Just as some agreements in restraint of trade are efficiency enhancing, ${ }^{48}$ sometimes excluding a competitor from the marketplace may enhance efficiency as well. ${ }^{49}$ As Robert Bork notes, "The problem is to know what exclusion is improper."

Efficiency itself is exclusionary, in the sense that inefficient firms lose market share and eventually are excluded from the market. ${ }^{51}$ Yet "exclusion

44. See id. at 1024.

45. Id. at 1027 .

46. As the discussion below makes clear, conduct is "improperly exclusionary" if it excludes a competitor from the market by means other than superior productive efficiency.

47. See United States v. Microsoft Corp., 253 F.3d 34, 58 (D.C. Cir. 2001) ("Whether any particular act of a monopolist is exclusionary, rather than merely a form of vigorous competition, can be difficult to discern ....").

48. See Nat'l Soc'y of Prof'l Eng'rs v. United States, 435 U.S. 679, 687-88 (1978) ("One problem presented by the language of $\S 1$ of the Sherman Act is that it cannot mean what it says. The statute says that 'every' contract that restrains trade is unlawful. But ... restraint is the very essence of every contract; read literally, $\S 1$ would outlaw the entire body of private contract law. Yet it is that body of law that establishes the enforceability of commercial agreements and enables competitive markets-indeed, a competitive economy-to function effectively." (footnotes omitted)).

49. See Robert H. Bork, The antitrust Paradox: A Policy at War with ITSelf 137 (1993).

50. Id.

51. Judge Hand's opinion in United States v. Aluminum Co. of America, 148 F.2d 416 (2d Cir. 1945), employed a literal view of exclusion to rebut defendant Alcoa's claim that taking market share from less efficient rivals was not improperly exclusionary. Hand wrote, "[W]e can 
[through superior efficiency] is proper and beneficial. It is the task of antitrust to see that it continues to operate." efficiency, with consumer welfare as the measure. ${ }^{53}$ For example, an efficient firm may take market share from a less efficient firm, or a firm may create a new productive efficiency that depends upon entering an exclusive dealing contract with certain suppliers or refusing to deal with a competitor. $^{54}$ But any exclusion that does not improve total consumer welfare is improper, such as exclusionary conduct that creates no productive efficiencies or creates greater allocative inefficiencies than productive efficiencies.

Evaluating the propriety of incompatibility decisions therefore requires an assessment of the productive efficiencies and allocative inefficiencies created by incompatibility. ${ }^{55}$ To illustrate this point, consider the D.C. Circuit's analysis of Microsoft's compatibility decisions regarding Java

think of no more effective exclusion than progressively to embrace each new opportunity as it opened, and to face every newcomer with new capacity already geared into a great organization .... [To] interpret 'exclusion' as limited to manoeuvres not honestly industrial .... would in our judgment emasculate the Act ...." Id. at 431; see also BORK, supra note 49, at 137 ("All business activity excludes. A sale excludes rivals from that piece of business.... The more efficient exclude the less efficient from the control of resources, and they do so only to the degree that their efficiency is superior.").

52. BORK, supra note 49 , at 137.

53. See id. at 61 (arguing that "competition" in antitrust statutes should be read as shorthand for a "state of affairs in which consumer welfare cannot be increased by moving to an alternative state of affairs"); see also United States v. Microsoft Corp., 253 F.3d 34, 58 (D.C. Cir. 2001) ("The challenge for an antitrust court lies in stating a general rule for distinguishing between exclusionary acts, which reduce social welfare, and competitive acts, which increase it."). But see Eleanor M. Fox, The Modernization of Antitrust: A New Equilibrium, 66 CORNELL L. REV. 1140 , $1147-48$ (1981) (arguing that the primary concern of the Sherman Act was to preserve competition between individuals and firms); Robert $\mathrm{H}$. Lande, Wealth Transfers as the Original and Primary Concern of Antitrust: The Efficiency Interpretation Challenged, 34 HASTINGS L.J. 65, 68-69 (1982) (arguing that the primary concern of the Sherman Act was to prevent wealth transfers from consumers to producers).

54. "Depends upon" is the operative phrase here. If the efficiency can be captured without the exclusive dealing contract, then the risk that such a contract will contribute to the dominant firm's market power should be counted as an inefficiency. In effect, a "least exclusive means" test should be employed, because where a nonexclusive or less exclusive means may accomplish the same productive efficiency, that state of affairs is to be preferred. See 3 PHILIP E. AREEDA \& HERBERT HOVENKAMP, ANTITRUST LAW: AN ANALYSIS OF ANTITRUST PRINCIPLES AND THEIR APPLICATION ๆ 651, at 72 (2d ed. 2002) (defining exclusionary conduct as "acts that (1) are reasonably capable of creating, enlarging, or prolonging monopoly power by impairing the opportunities of rivals; and (2) that ... [inter alia] are unnecessary for the particular consumer benefits that the acts produce"). The Court in Aspen Skiing Co. v. Aspen Highlands Skiing Corp., 472 U.S. 585 (1985), quoted with approval a similar definition of exclusionary conduct. Id. at 605 n.32.

55. Productive efficiency is maximized when the greatest possible value is created using the least possible resources. Allocative efficiency describes the state in which "[a]ll goods and services would be appropriately allocated, [i.e., allocated to those who value them most,] and preferences for leisure met, because, by definition, no further acts or exchanges could make the situation better." THOMAS D. MORGAN, MODERN ANTITRUST LAW AND ITS ORIGINS 9 ( $2 \mathrm{~d}$ ed. 2001). 
technologies in United States $v$. Microsoft Corp. ${ }^{56}$ Sun Microsystems created Java technologies. Later, Microsoft developed its own Java Virtual Machine (JVM), which "allow[ed] Java applications to run faster on Windows than [did] Sun's JVM," but it designed its JVM such that "a Java application designed to work with Microsoft's JVM [would] not work with Sun's JVM and vice versa." ${ }^{, 57}$ The government claimed that Microsoft improperly excluded Sun by designing its JVM to be incompatible with Sun's JVM. The court stated the test for improper exclusion as whether the incompatible product has "an anticompetitive effect that outweighs any procompetitive justification for the design." 58 Ultimately, the court concluded that Microsoft's actions were efficient because its JVM "does allow applications to run more swiftly and does not itself have any anticompetitive effect." 59

The court erred, however, by failing to apply its own standard rigorously. The aspect of Microsoft's conduct that was allegedly anticompetitive was not its decision to make a faster JVM but its decision to make its JVM incompatible with Sun's JVM. Therefore, unless incompatibility was a necessary condition for achieving the enhanced speed of Microsoft's JVM, the increased speed could not justify the incompatibility. Yet the court's analysis failed to focus on the anticompetitive effects of Microsoft's incompatibility decision and instead addressed the anticompetitive effects of the JVM itself. Because moves to incompatibility reduce network benefits to consumers, such moves should be tolerated only where necessary to increase productive efficiency.

A court analyzing the efficiencies of a move to incompatibility must have a baseline - an alternate state of affairs-against which to compare the challenged conduct. ${ }^{60} \mathrm{~A}$ firm that chooses between compatibility and incompatibility is shaping the future; therefore, the proper analytical baseline is the alternate state of affairs that would have developed but for the allegedly exclusionary act. In some circumstances, as in mature industries with relatively static technologies, the past may provide important evidence of future optimality, ${ }^{61}$ but in at least two circumstances-nascent industries with rapidly changing technology and

56. See 253 F.3d at 74 . According to the court, "Java technologies include: (1) a programming language; (2) a set of programs written in that language ...; (3) a compiler, which translates code written by a developer into 'bytecode'; and (4) a Java Virtual Machine ('JVM'), which translates bytecode into instructions to the operating system." Id.

57. Id.

58. Id. at 75 .

59. Id.

60. The same analysis applies to decisions maintaining the status quo of incompatibility over a move to compatibility.

61. See, e.g., BORK, supra note 49 , at 156 ("In any business, patterns of distribution develop over time; these may reasonably be thought to be more efficient than alternative patterns of distribution that do not develop."). 
industries moving from regulation to deregulation-there is reason to doubt that past patterns of conduct represent optimality. Our analysis, therefore, must focus on the market as it could have been but for the challenged conduct.

The Microsoft court compared the result of Microsoft's actions-a faster JVM and two incompatible standards-with the past status quo-a slower JVM and a single JVM standard. ${ }^{62}$ A proper analysis would have compared the state of affairs in which Microsoft's JVM was incompatible with Sun's against one in which the two were compatible. By focusing on Microsoft's choice between a compatible and an incompatible future, the relevant line of inquiry would have become clear: What productive efficiencies were possible only in the incompatible world, and what efficiencies were possible only in the compatible world? Any efficiencies that would have existed independent of the compatibility decision are neutral and shed no light on the welfare effect of compatibility relative to incompatibility.

In contrast to the Microsoft court's flawed approach, the Supreme Court's decision in Aspen Skiing Co. v. Aspen Highlands Skiing Corp. in many ways exemplifies the ideal mode of analysis for compatibility decisions. ${ }^{63}$ Though the Court's opinion did not employ the vernacular of network economics, the facts of the case confirm the descriptive utility of economic theories of compatibility and interconnection pricing, and the Court's analysis provides a useful template for assessing the consumer welfare implications of compatibility decisions.

The basic facts of Aspen Skiing are as follows: Aspen, Colorado was a destination ski resort with four mountains. Aspen Skiing Company (Ski Co.) owned three of the mountains; Aspen Highlands Skiing (Highlands) owned the fourth. ${ }^{64}$ Between 1967 and 1977, the two companies jointly marketed an all-Aspen pass that could be used at any of the four mountains and divided revenue according to how many skiers accessed each mountain using the pass. ${ }^{65}$ The Court noted that "[m]ost experienced skiers quite logically prefer to purchase their tickets at once for the whole period that they will spend at the resort; they can then spend more time on the slopes... and less time standing in ticket lines." ${ }^{.66}$ In addition, the allAspen pass "expanded the vistas and the number of challenging runs available" to passholders. ${ }^{67}$

62. See Microsoft, 253 F.3d at 75.

63. 472 U.S. 585 (1985).

64. See id. at $588-90$.

65. Originally this was accomplished by writing down the ticket numbers of persons going onto the slopes, and later by random-sample survey. See id. at 590 .

66. Id. at 605 .

67. Id. at 606. Hence, network benefits were maximized. See supra notes 25-26 and accompanying text (explaining that achieving compatibility among rival systems maximizes network benefits). 
In 1978, Ski Co. officials refused to cooperate with Highlands in offering the four-mountain pass on terms that were acceptable to Highlands, so the companies ended the four-mountain pass. ${ }^{68}$ Thereafter, Highlands quickly began losing market share to Ski Co.'s three-mountain, multiday ticket, and was thwarted in its unilateral efforts to offer consumers the benefits of the four-mountain pass. ${ }^{69}$

The Aspen Skiing firms' behavior presents a textbook example of network competition. Ski Co. had a dominant overall package (three mountains versus one). Highlands had some distinctly superior components, ${ }^{70}$ but an inferior overall package. Predictably, Ski Co. realized that it would fare better if it thwarted cross-company skiing in Aspen (i.e., if it imposed incompatibility), even though in so doing it created an allocative-efficiency loss by eliminating a desirable product from the market. ${ }^{71}$ Highlands's preference for compatibility and its unilateral efforts to create an adapter (i.e., an alternative four-mountain pass) likewise demonstrate the behavior predicted by network economic theory for a firm in Highlands's position. ${ }^{72}$ Finally, Ski Co.'s response of raising daily ticket prices exhibits the interconnection-pricing behavior anticipated by Economides's model, ${ }^{73}$

The central question for the Aspen Skiing Court was if and when a monopolist has a duty to cooperate with a competitor. Ski Co. argued that antitrust laws never impose such a duty and that unilateralism is the hallmark of competition, ${ }^{74}$ which in turn is what antitrust laws aim to

68. See id. at 593 .

69. Highlands offered a six-day "Adventure Pack," which contained its own lift tickets plus three vouchers redeemable for Ski Co. tickets. Ski Co. refused to accept the vouchers, even though they were guaranteed by funds deposited at a local bank. See id. at 594. Thereafter, Highlands switched from vouchers to traveler's checks equal to the price of Ski Co. tickets. See id. Ski Co. accepted these; as the Court noted, there was no way for Ski Co. to tell whether the checks came from Highlands, so Ski Co.'s attempts to completely freeze Highlands out were thwarted. See id. Shortly thereafter, however, Ski Co. raised its daily ticket prices to a level that made the Adventure Pack prohibitively expensive relative to Ski Co.'s three-mountain pass. See id. In fact, on appeal to the Tenth Circuit, Highlands claimed that one of Ski Co.'s six anticompetitive actions was "raising ticket prices for a single-day lift ticket thus eliminating plaintiff's ability to offer a multi-area ticket." Aspen Highlands Skiing Corp. v. Aspen Skiing Co., 738 F.2d 1509, 1517 (10th Cir. 1984), aff'd, 472 U.S. 585 (1985).

70. For example, Highlands had a distinctly superior ski instruction school. See Aspen Skiing, 472 U.S. at 595 n.17.

71. See id. at 605-07 (noting that consumers preferred the all-Aspen pass to a three-mountain pass).

72. See supra Subsection I.C.1.

73. Cf. Economides et al., supra note 39, at 1019 n.2.

74. Interestingly, American Airlines filed an amicus brief arguing against a finding of antitrust liability in Aspen Skiing. Brief of Amicus Curiae American Airlines, Aspen Skiing (No. 84-510). American stated its general belief that Ski Co. was under no duty to deal with Highlands. See id. at $1 \mathrm{n} .1$. It also specifically expressed concem as to the Tenth Circuit's holding that Ski Co. acted improperly by making its continued participation in the four-mountain pass contingent on financially unacceptable terms during the 1977-1978 season. See id. at 3-4. According to American, an owner of an essential facility acts legally per se by granting access to that facility, 
protect. $^{75}$ The Court, however, cited Lorain Journal Co. v. United States ${ }^{76}$ for the proposition that the right of unilateralism does not extend to anticompetitive, exclusionary, or predatory refusals to deal. ${ }^{77}$ The test, according to the Court, is whether "valid business reasons exist for that refusal." 78

At the heart of the Court's analysis, and essential to understanding the role of network economics in this case, is the Court's definition of what makes a business reason "valid." The Court stated simply that "[i]f a firm has been attempting to exclude rivals on some basis other than efficiency, it is fair to characterize its behavior as predatory." Improperly exclusionary behavior includes "that [which] not only (1) tends to impair the opportunities of rivals, but also (2) ... does not further competition on the merits." $" 80$

With this analytical framework in place, the Court examined the effect of the challenged conduct on competition, competitors, and consumers. It found that Ski Co. had narrowed the choices available to consumers by insisting upon competition at the network level, which forced consumers to choose either Ski Co. or Highlands but not both. ${ }^{81}$ The Court accurately observed that since Ski Co.'s withdrawal did not create any new efficiencies, its conduct resulted in a net reduction in consumer welfare. ${ }^{82}$ Thus, unlike exploiting supply-side economies of scale, which may give the larger firm an advantage over smaller rivals by decreasing the cost of production, ${ }^{83}$ exploiting superior network size by creating incompatibility with rivals merely creates a competitive advantage at the expense of consumers. ${ }^{84}$

regardless of the terms the owner dictates. See id. at 9 ("While the antitrust laws may impose a duty to deal in certain cases, they do not inject the judiciary into the minutiae of setting the terms on which the parties must deal.").

75. See Aspen Skiing, 472 U.S. at 600-01.

76. 342 U.S. 143 (1951).

77. See Aspen Skiing, 472 U.S. at 601-03.

78. Id. at 605.

79. Id. (internal quotation marks omitted); see also Einer Elhauge, Defining Better Monopolization Standards, 56 STAN. L. REV. 253, 323, 323-24 (2003) ("The key factor that distinguishes the sort of exclusionary conduct that merits condemnation is that it can successfully increase or maintain the monopolist's market power even if the monopolist has not increased its efficiency in any way.").

80. Aspen Skiing, 472 U.S. at 605 n.32 (internal quotation marks omitted).

81. See id. at 606.

82. As evidence of this welfare loss, the Court cited consumer surveys that found that "in the 1979-1980 season . . 53.7\% of the respondents wanted to ski Highlands, but would not; $39.9 \%$ said that they would not be skiing at the mountain of their choice because their ticket would not permit it." Id.

83. See BORK, supra note 49 , at $310-14$.

84. See Aspen Skiing, 472 U.S. at 608 . The Court noted that the jury may have concluded that "Ski Co. elected to forgo ... . [daily ticket sales] because it was more interested in reducing competition in the Aspen market over the long run by harming its smaller competitor." Id. 
By combining the reasoning of Microsoft and Aspen Skiing, it is possible to derive an analytical framework for evaluating compatibility and interconnection decisions. The first step is to identify incompatibilities that exist in the market. The next step is to identify those productive efficiencies for which incompatibility is a necessary condition and weigh them against any productive or allocative efficiencies for which compatibility is a necessary condition. If incompatibility creates a net welfare loss, then firms' behavior in perpetuating incompatibility is improperly exclusionary.

The next two Parts apply this general analysis to the airline industry. Part III examines the history of the airline industry and identifies incompatibilities among competing airline networks. Part IV suggests a rules-based regulatory regime to achieve compatibility and nondiscriminatory interconnection in the airline industry and, using the Aspen Skiing approach, compares the welfare effects of incompatibility with the likely costs and benefits of compatibility under the proposed regulation.

\section{COMPETITION AND COMPATIBILITY AMONG AIRLINE NETWORKS}

Although the airline industry consists of competing networks, the potential analytic power of network theory as applied to airline firms' behavior has received little attention. Yet, as I argue below, compatibility and interconnection-pricing behavior by dominant firms in the market has played and continues to play an important role in preserving the dominant networks' market share, in spite of substantially higher costs. Section A briefly recounts the history of the airline industry to provide a backdrop against which Section B explores how compatibility theory may explain heretofore perplexing firm behavior.

\section{A. The History of Airline Competition}

Until deregulation in the late 1970 s, airline networks generally were characterized by a point-to-point structure rather than a hub-and-spoke structure. ${ }^{85}$ Compared to today's market, a higher proportion of travelers flew directly to their destinations without making a transfer. ${ }^{86}$ Among those

According to the Court, this "conclusion is strongly supported by Ski Co.'s failure to offer any efficiency justification whatever for its pattern of conduct." Id.

85. See Michael E. Levine, Airline Competition in Deregulated Markets: Theory, Firm Strategy, and Public Policy, 4 YALE J. ON REG. 393, 413 (1987).

86. See Severin Borenstein, The Evolution of U.S. Airline Competition, J. ECON. PERSP., Spring 1992, at 45,49 ("The share of trips over 1500 miles that involve a flight change rose from 42 percent in 1978 to 52 percent in 1990 . On trips between 500 and 1500 miles, it increased from 33 percent in 1978 to 38 percent in 1990."); see also Dennis W. Carlton et al., Benefits and Costs 
passengers who did not fly nonstop to their destinations, a significant proportion divided their itineraries between two or more airlines. ${ }^{87}$

As Michael Levine pointed out in his seminal 1987 article, many economists believed that deregulation would produce outcomes close to the results of perfect competition. ${ }^{88}$ Airline markets were, it was said, perfectly contestable, because the industry's basic inputs-aircraft and personnelwere highly mobile, ${ }^{89}$ firms could increase or decrease their scale at any given airport without incurring sunk costs, ${ }^{90}$ and firms did not face significant economies of scale. ${ }^{91}$ Based on these factors, some economists predicted that the industry would become much less concentrated, though this was not a unanimous sentiment. ${ }^{92}$ In addition to having had expectations regarding the structure of the deregulated industry, many economists formed expectations about the fate of particular airline firms. For example, it was widely thought that legacy firms--those that had existed under regulation - would all but disappear after deregulation. ${ }^{93}$

As it turned out, after Congress passed the Airline Deregulation Act of $1978,{ }^{94}$ the industry briefly became less concentrated as entry increased, but soon became significantly more concentrated than it had been under regulation. ${ }^{95}$ By 1983 , "entry of new airlines slowed markedly and came to a nearly complete halt." "96 Additionally, the large, high-cost legacy airlines seemed to be the only firms surviving in the market, while newer firms either failed or were acquired by legacy airlines. ${ }^{97}$

of Airline Mergers: A Case Study, 11 BELL J. ECON. 65 (1980) (noting the significant consumer benefit from on-line rather than off-line transfers).

87. According to Severin Borenstein, "The proportion of trips that included a change of airline fell from 11.2 percent in 1978 to 6.9 percent in 1981 [following deregulation], 4.0 percent in 1984, and 1.2 percent in 1987 and 1990." Borenstein, supra note 86, at 50. Although some of the later decreases are due to market concentration following mergers among major carriers, Borenstein argues that "the earlier and more significant declines are explained largely by formation of hub-and-spoke systems." Id.

88. See Levine, supra note 85 , at 400.

89. See id. (citing CAVES, supra note 2).

90. See id.

91. See id. (citing Robert J. Gordon, Airline Costs and Managerial Efficiency, in TRANSPORTATION ECONOMICS 61 (1965); and Lawrence J. White, Economies of Scale and the Question of "Natural Monopoly" in the Airline Industry, 44 J. AIR L. \& COM. 545 (1979)).

92. See Borenstein, supra note 86 , at $45-46$.

93. See Levine, supra note 85, at 405-06.

94. Pub. L. No. 95-504, 92 Stat. 1705 (current version in scattered sections of 49 U.S.C.).

95. See Borenstein, supra note 86, at 47 (noting that the Herfindahl-Hirschman Index (HHI), which measures industry concentration, increased for the airline industry from 0.106 in the prederegulation year of 1977 to 0.123 in 1987 and 0.121 in 1990).

96. Id.

97. See Levine, supra note 85 , at 406-07 (noting that the ten largest domestic airlines in 1986 were all legacy airlines); see also Borenstein, supra note 86 , at 48 fig. 1 . 
Other surprises soon followed. In his history of airline competition, Levine, who offers both an analytical and anecdotal account, ${ }^{98}$ identifies two important airline structural strategies that confounded economists. First, many airlines engaged in, or sought to engage in, both horizontal and vertical mergers, ${ }^{99}$ even though, as Levine points out,

[v]ery few, if any, production economies explain the inexorable pressures to combine by consolidation or contract the international and domestic long-haul, domestic short- and medium-haul, and local feeder segments of the industry. In fact, for many years, it was something of an accepted fact in the industry and among scholars that such combinations were inefficient because they imposed the overhead and labor costs of the higher-density, longer-haul modes on the shorter-haul, lower-density operations. ${ }^{100}$

Second, the linear point-to-point structure that predominated under regulation was replaced by a nearly pervasive hub-and-spoke system. ${ }^{101}$ While some have praised the hub-and-spoke system for its efficiency, ${ }^{102}$ many others have also described its utility as an entry-deterrence strategy. ${ }^{103}$

Strikingly, the success of the legacy airlines' structural strategies cannot be explained entirely by reference to efficiency. ${ }^{104}$ And, although the hub-and-spoke system theoretically offers improved efficiency over a linear

98. Levine has served as general director for international and domestic aviation at the Civil Aeronautics Board, executive vice president of marketing at Continental Airlines, and president and chief executive officer of New York Air, and was, at the time he wrote his 1987 article, a law professor at the University of Southern California. See Levine, supra note 85, at $393 \mathrm{n} . \dagger$.

99. See id. at 408-11.

100. Id. at 410 (footnote omitted).

101. See Borenstein, supra note 86 , at 48 ; Levine, supra note 85 , at 411-13.

102. See, e.g., Borenstein, supra note 86 , at 49 ("This approach has allowed carriers to fill a higher proportion of the seats on their planes and to increase flight frequency of nonstop routes between their hubs and other airports."); Eli A. Friedman, Comment, Airline Antitrust: Getting Past the Oligopoly Problem, 9 U. MIAMI BUS. L. REV. 121, 125-26 (2001) ("The 'hub and spoke' system is extremely efficient .... Any new entrant in the industry must either have a 'hub and spoke' system or another type of efficiency in order to be competitive.").

103. See, e.g., OZ SHY, THE ECONOMICS OF NETWORK INDUSTRIES 218-24 (2001); Joseph Berechman et al., Network Structure and Entry in the Deregulated Airline Industry, 35 KEIO ECON. STUD. 71, 74-81 (1998); Ken Hendricks et al., Entry and Exit in Hub-Spoke Networks, 28 RAND J. ECON. 291, 292-300 (1997); Levine, supra note 85, at 411-13.

104. As Levine bluntly explains,

Holdover airlines have learned to compensate for above-market costs by successfully pursuing revenue-earning strategies that generate rents and have not-and perhaps cannot-be duplicated by smaller new-entrant firms with lower production costs. They have learned as well to use their holdover position and size advantages to impose costs on these rivals, thus narrowing the production cost differences.

Levine, supra note 85 , at 408 . 
system, the legacy hub-and-spoke airlines still had much higher costs than most entrants. ${ }^{105}$ As Levine notes,

Contractual commitments of various kinds, including such items as unproductive and expensive labor arrangements, purchase debts, or long-term leases of unsuitable equipment built in costs for holdover airlines higher than those experienced by new entrants. If committed costs, information lags, transaction costs, firm-specific investments, and sheer human inertia play a role in the behavior of real-world airlines, holdover firms should have been at a disadvantage .... [which] should have resulted in the holdover firms' being replaced by new entrants, or at least transforming themselves into carriers with new-entrant costs. ${ }^{106}$

But, to the surprise of many observers, the legacy airlines survived and thrived without trimming their costs to competitive levels. ${ }^{107}$ Even today, as the legacy airlines struggle for market share against a bevy of low-cost competitors, much of the competition has been somewhat indirect-"on the rim"108 or in secondary airports. ${ }^{109}$ Legacy airlines remain dominant in the industry, and their hub-and-spoke route structure is still the industry's single most important structural characteristic. ${ }^{110}$

How can this be explained? One piece of the puzzle relates to the huband-spoke model. Economists studying networks have demonstrated that network-structure decisions are strategic and that adopting a hub-and-spoke structure is an effective means of entry deterrence. ${ }^{111}$ Part of this deterrence stems from the market power that hubbing creates on flights that originate or terminate at the hub. Since the hubbing airline typically controls a large proportion of the flights in and out of its hub airport, it can raise fares on

105. See id. at 407.

106. Id. at 406 (footnote omitted).

107. In 1990, the least efficient airline's costs were sixty-four percent higher than the most efficient airline's. See Borenstein, supra note 86, at 60; see also Michael E. Levine, Op-Ed, No Clear Way Forward for Airlines, N.Y. TIMES, Dec. 6, 2002, at A35.

108. That is, nonstop service between two nonhub cities. See Levine, supra note 107 ("The very same hub-and-spoke system the airlines created in response to deregulation is now being exploited by the discount airlines, which operate on its fringes.").

109. For example, low-cost carrier ATA has established a presence at Chicago's Midway Airport rather than O'Hare, the city's primary airport, while JetBlue serves the Los Angeles region from the small Long Beach Airport rather than from LAX.

110. In 2003, legacy hub-and-spoke airlines accounted for sixty-seven percent of total passenger emplanements. See Commercial Aviation: Despite Industry Turmoil, Low-Cost Airlines Are Growing and Profitable: Testimony Before the Subcomm. on Aviation of the House Comm. on Transp. and Infrastructure, 108th Cong. 4 (2004) (testimony of JayEtta Z. Hecker, Dir., Physical Infrastructure, GAO) [hereinafter GAO Testimony].

111. See, e.g., SHY, supra note 103, at 218-24; Berechman et al., supra note 103, at 74-81; Hendricks et al., supra note 103, at 292-300. 
those flights without fear of competitive entry. ${ }^{112}$ Furthermore, an airline's dominant presence at its hub may allow it to exert veto power over any plans to expand the airport's capacity, ${ }^{113}$ which further limits the possibility of competitive entry and its attendant check on market power. ${ }^{114}$ According to some scholars, having a large network also enables legacy airlines to price predatorily on routes served by entrants, thereby causing the entrant to expend cash reserves and exit the market ${ }^{15}$ while the incumbent "experiences an economy of scope in the value of reputation for fierceness as a deterrent to other entrants in other markets or in the future."116

In addition, a hub-and-spoke system has significant advantages over a point-to-point system, insofar as it allows an airline to provide frequent flights to and from small cities by combining travelers with a common origin and diverse destinations on a single flight to the hub. Likewise, flights from the hub combine passengers with diverse origins and a common destination. For those traveling between two small cities, the huband-spoke system allows for more frequent flights on larger aircraft than would be offered for direct flights. Once a leader puts its hub structure in place, it is difficult to enter the market for connecting passengers, except on a very broad scale. ${ }^{117}$ Moreover, the constrictions of airport capacity are an additional barrier to entry on a large scale. ${ }^{118}$

112. See Severin Borenstein, Hubs and High Fares: Dominance and Market Power in the U.S. Airline Industry, 20 RAND J. ECON. 344, 357 (1989) ("[A] 1\% increase in a carrier's share on the route is estimated to increase its prices by between $0.03 \%$ and $0.22 \%$. Ceteris paribus, a dominant airline on a route with a $70 \%$ share of the traffic might be able to charge from $2 \%$ to $12 \%$ higher prices than its rivals which have only $10 \%$ shares.").

113. Airlines often help finance construction, expansion, and remodeling of their hub airports. In exchange, an airline may insist upon a majority-in-interest clause in its lease, which grants it authority to veto further expansion of the airport. For an overview of the role majority-ininterest clauses play in airline competition, see Russell A. Klingaman, Predatory Pricing and Other Exclusionary Conduct in the Airline Industry: Is Antitrust Law the Solution?, 4 DEPAUL BUS. L.J. 281, 331-35 (1992).

114. See Borenstein, supra note 112 , at 356.

115. See Levine, supra note 85 , at 445 ("The rents attracting entry can be made to disappear temporarily as a result of price cuts and capacity increases, the impacts of which fall particularly heavily on the new entrant .... [because a] large, better known, multi-hub incumbent can attract more traffic at any given price level than the new entrant.").

116. Id. The Justice Department adopted this predatory-reputation theory in its antitrust suit against American Airlines for alleged predatory pricing on routes connecting to its Dallas hub. See United States v. AMR Corp., 335 F.3d 1109, 1111 (10th Cir. 2003). But see Einer Elhauge, Why Above-Cost Price Cuts To Drive Out Entrants Are Not Predatory-and the Implications for Defining Costs and Market Power, 112 YALE L.J. 681 (2003) (arguing that restricting an incumbent's ability to deter entry with reactive above-cost price cuts would invite entry by less efficient firms and reduce consumer welfare).

117. The major airlines' practice of entering code-sharing agreements with regional commuter airlines, in which a major airline sells tickets on commuter airlines under its own airline code designation, makes entry still more difficult. Such arrangements also allow on-line baggage handling and one-stop check-in for travelers on a mixed major/regional itinerary, but they frequently place regional competitors at a disadvantage in the market for connecting flights. See 1 PAUl DEMPSey et al., AVIATION LAw AND Regulation $\S 6.02$ (1992); see also 1 id. $\S 5.05$ 
The legacy airlines' survival has also been attributed to a variety of nonstructural factors. Prominent among them are two related marketing devices: frequent flier programs (FFPs) and travel-agent commission override (TACO) programs. ${ }^{19}$ Although such programs have undoubtedly been important in the past, particularly with regard to business travelers, ${ }^{120}$ the recent trend among businesses to seek out low-cost travel options and the rapidly increasing use of the Internet to book airline tickets both herald a significant reduction in the impact of such incentive programs. ${ }^{121}$

In recent years, bloated costs have finally begun to weigh heavily upon the legacy airlines. Since 2001, legacy airlines have recorded operating losses totaling almost twenty-five billion dollars. ${ }^{122}$ Meanwhile, low-cost airlines have remained profitable throughout the same period and have gained market share. ${ }^{123}$ It may be that we are witnessing the early stages of a terminal erosion of legacy airlines' market share and influence. However,

(finding that major carriers with code-sharing arrangements charge eight percent higher fees); Borenstein, supra note 86, at 59 (arguing that while code sharing and equivalent vertical mergers with regional carriers "permit greater coordination of flight schedules, baggage handling, marketing, and frequent flyer programs, which may increase the consumer's value of the joint product .... . they can raise the costs of entry for a new airline at airports where the major and the commuter airline connect"); Roger Collis, Code-Sharing Alliances: Not Always in the Flier's Interest, INT'L HERALD TRIB. (Paris), May 8, 1998, at 11, available at http://www.iht.com/IHT/ $\mathrm{RC} / 98 / \mathrm{rc} 050898$ html (describing criticism of such arrangements but noting the benefit travelers gain from seamless check-in and baggage handling).

118. See Kelly Quigley, Critics Blast O'Hare Expansion, ChiCagoBusiness.COM, Jan. 16, 2004, http://chicagobusiness.com/cgi-bin/news.pl?post_date=2004-01-16\&id=1 1204\&rel=1; see also Levine, supra note 85 , at 444-45 ("An airline large enough to exhaust production indivisibilities at even a medium-sized city hub is already a pretty big airline. None of the approximately twenty-rive cites [sic] being used as a hub at this writing supports more than two such airlines, and most support only one. A would-be entrant at a hub city must therefore be prepared to displace an incumbent." (footnotes omitted)).

119. See, e.g., Borenstein, supra note 86, at 62-63 (describing the strategic importance of FFPs and TACOs to incumbent airlines). TACO programs allow travel agents to earn increased commissions for booking flights on a particular airline. Like FFPs, the object of TACOs is to encourage agents to concentrate bookings with sponsor airlines.

120. Business travelers exhibit the greatest degree of principal/agent disconnect in purchasing airline tickets. Loyalty incentive programs benefit the agents (the employee and the travel agent), while the principal (the entity paying for the airline tickets) imperfectly monitors the agents' actions, leaving open the possibility that agents will place a much higher value on reduced travel time or frequent flier miles than on lower price because the benefits of lower prices redound only to the employer. A business traveler will value frequent flier miles earned on a large network airline more than on a small point-to-point airline, because the larger airline offers more desirable destinations when one redeems the frequent flier miles. See Levine, supra note 85, at 452-58.

121. See, e.g., Micheline Maynard, The East Joins the Low-Fare Bazaar, N.Y. TIMES, Feb. 8 , $2004, \S 3$ (Money \& Business), at 1 (noting that business travelers account for a large share of fares on many low-cost carriers, owing to the fact that "[c]orporations are not approving those budgets" for expensive business-class fares on legacy airlines and that "[e]verybody is looking for a deal" (internal quotation marks omitted)).

122. See GAO Testimony, supra note 110 , at 1 .

123. See id. at 4 ("Between 1998 and 2003 ... low-cost airlines increased their presence in the 5,000 largest city pair markets (e.g., New York-Boston) from 32 to 46 percent and increased overall market share of passenger enplanements from 23 to 33 percent."). 
as I argue in Part IV, dominant firms will have incentives to preserve incompatibility with smaller rivals, at the expense of consumer welfare, so long as hubbing remains important to the industry. For this reason, compatibility and interconnection pricing will continue to be significant even if Southwest and JetBlue displace the legacy airlines as the industry's most powerful players. Today's low-cost carriers may, after all, become tomorrow's dominant hub-and-spoke airlines.

\section{B. Network-Compatibility Theory and the Airline Industry}

Though scholars have explored some ways in which the hub-and-spoke model insulates airlines from competition, the scholarship to date has neglected an important theory explaining the outcomes we have witnessed in the airline market. Network-compatibility theory provides a useful tool for understanding the power of the current intrafirm hub-and-spoke model as an exclusionary firm strategy.

This Section attempts to fill this gap in the scholarship by applying economic models of compatibility decisions and interconnection pricing to the airline industry. This effort is important because it accounts for phenomena that have strained the current array of explanations. Employing compatibility and interconnection theory does not necessarily challenge other theories that have attempted to explain airline behavior; instead, adding this theory to the others provides a clearer picture of the industry.

Furthermore, this approach is prescriptively useful. Compatibility theory illuminates an important part of the incentive structure driving airline behavior and suggests some relatively simple and unobtrusive regulatory measures that may produce a market structure that increases consumer welfare. ${ }^{124}$

\section{Modeling Compatibility and Interconnection Pricing Among Airline Networks}

Many segments of the airline network are complementary-i.e., they may potentially combine to produce a travel itinerary. Yet, in Nicholas Economides's phrase, "it is compatibility that makes complementarity actual." 125 Compatibility means the ability to use two goods together without prohibitive cost. ${ }^{126}$ Though some products are inherently complementary-matches and cigarettes, for example-“"for many complex products, actual complementarity can be achieved only through the

124. See infra Part IV.

125. Economides, supra note 8, at 676 (emphasis omitted).

126. See supra Section I.C. 
adherence to specific technical compatibility standards." 127 At times, though, some dominant firms may prefer incompatibility and therefore will deviate from a standard or oppose creation of a standard. ${ }^{128}$

Economides's telecommunications model demonstrates that unregulated competition between rival networks will make inter-network calls more expensive than intra-network calls because the dominant network will raise the price of individual network components relative to the implicit internal price it charges its own members. ${ }^{129}$ Such pricing strategies predictably tend to exclude entrants from the market and entrench the larger network's dominance. ${ }^{130}$ Of course, the structure of telecom networks is very different from the structure of airline networks. Telecom consumers do not choose among networks each time they place a call; they buy a subscription. Airline consumers, by contrast, generally choose among airlines on a flight-by-flight basis.

Nevertheless, the Economides model is relevant to the airline market because a dominant airline network's incentive and ability to manipulate consumer choice through discriminatory interconnection pricing is similar to that of a dominant telecom network. For example, assume the air travel market is composed of two airlines: Dominant, a large hub-and-spoke carrier, and Entrant, a small point-to-point carrier. As Figure 2 depicts, Dominant has six routes into and out of its hub in Chicago, while Entrant has only one route into and out of Chicago. Assuming the absence of logistical incompatibilities between rival networks ${ }^{131}$ (i.e., a traveler going from St. Louis to Flint finds it equally convenient to fly itinerary $E_{1}-D_{4}$ as to fly itinerary $D_{l}-D_{4}$ ) and nondiscriminatory interconnection pricing (i.e., route prices for inter-network connecting passengers equal the implicit price for intra-network connecting passengers), consumers choosing an itinerary will be indifferent to the size of the airline's network and will have no preference for intra-network itineraries. Thus on the route it serves, Entrant may compete for connecting passengers as well as those whose origin or destination is the hub. So, for example, assume Dominant prices travel from St. Louis to Flint at $\$ 100$, and individually prices flights $D_{l}$ and $D_{4}$ at $\$ 50$ each. Assume further that Entrant offers flight $E_{1}$ between St. Louis and Chicago for $\$ 40$. If flights $D_{l}$ and $E_{l}$ are equally convenient, consumers traveling from St. Louis to Chicago or any spoke city will

127. Economides, supra note 8 , at 676-77.

128. See supra Subsection I.C.1.

129. See Economides et al., supra note 39 , at 1024.

130. See id. at 1021 ("When users attach little weight to differences between the networks, and when their price structures are similar, then the larger network will be preferred so long as internal calls are priced at a discount. In that event, we will see a 'tipping' of the market, resulting in only one active network.").

131. See infra notes $136-140$ and accompanying text. 
uniformly choose to fly Entrant for the St. Louis to Chicago leg, then connect to a flight on Dominant.

FIGURE 2. AN AIRLINE NETWORK

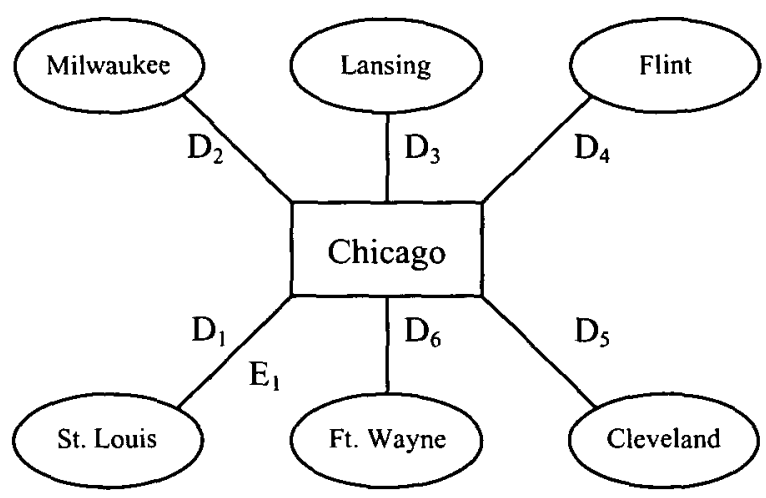

However, in the airline market, as in the Economides telecom model, a dominant network may prevent small entrants from competing for connecting passengers by charging discriminatory interconnection fees. ${ }^{132}$ Assume that Dominant continues to charge $\$ 100$ for the complete itinerary from St. Louis to Flint, but begins charging $\$ 70$ for flights $D_{1}$ or $D_{4}$ if purchased separately. The price of inter-network travel from St. Louis to Flint increases to $\$ 110$, and consumers traveling from St. Louis to Flint will no longer fly on Entrant. If Dominant imposes similar prices for all its routes, Entrant will be excluded from the market for connecting passengers. Dominant will thereby increase its market share on flights from St. Louis to Chicago. The result is allocative and productive inefficiency. ${ }^{133}$

Moreover, because an airline's cost per passenger is dictated by a flight's load factor, ${ }^{134}$ when Entrant is excluded from the market for connecting passengers, it will likely experience an increase in its cost per passenger. Consequently, Entrant's ability to compete for passengers originating or terminating at the hub will suffer because operating in such a thin market may drive Entrant's load factors down to the extent that it no

132. The larger network will prefer incompatibility where it has a more desirable overall package than smaller competitors. See supra Subsection I.C.1.

133. Allocative inefficiency results insofar as some passengers who would have flown from St. Louis to Flint at the competitive $\$ 90$ fare will not fly at the $\$ 100$ fare and will instead spend their resources in some other, second-best way. Productive inefficiency results because Dominant consumes more resources in providing service between St. Louis and Chicago than Entrant would consume.

134. "Load factor" refers to the percentage of seats on each flight that are sold. The higher the load factor, the larger the denominator in calculating per-passenger costs. 
longer has a cost advantage over Dominant. Thus, by engaging in discriminatory interconnection pricing, Dominant may simultaneously exclude Entrant from the connecting market and harm Entrant's ability to compete in the market for hub passengers (passengers who originate or terminate at the hub) by raising Entrant's costs.

\section{Observing Compatibility and Interconnection Pricing in the Airline Market}

In the airline industry today, we observe actual complementarity among different route segments almost exclusively in the limited contexts of intranetwork itineraries and code-sharing arrangements. Complementarity between flights on rival airline networks is only potential, not actual, because the cost of combining flights makes such an itinerary prohibitively expensive compared to an itinerary within a single network. ${ }^{135}$

There are currently two significant logistical costs associated with interairline travel: consumers' inability to check in for their entire itinerary and the need to reclaim checked luggage from one carrier and recheck it with the second carrier between connecting flights. ${ }^{136}$ Often this requires a passenger to leave an airport's secure area, claim and recheck her luggage, and pass through another security screening before making her connection. The cost in time and effort required for such an operation is prohibitive, making "off-line" transfers extremely rare. ${ }^{137}$

Some costs of off-line connections may inhere in the nature of the industry and may therefore be unavoidable. ${ }^{138}$ For instance, some

135. In an early study of airline mergers after deregulation, Dennis Carlton, William Landes, and Richard Posner identified a significant consumer preference for intra-network versus internetwork transfers in the context of a specific merger. See Carlton et al., supra note 86, at 67-68. They compared city pairs that were served by both single and multiple carriers with similar fares, travel times, and frequencies. The authors modeled consumers' utility functions for travei on multiple carriers versus a single carrier, and found that based on the full costs of air travel (i.e., fare plus the consumer's value of time), single-carrier service offered benefits of $7.0 \%$ to $9.8 \%$ over multiple-carrier service. Accordingly, on the city-pair routes studied, single carriers' market share was approximately three times that of multiple carriers. The authors also identified other benefits of single-carrier services, such as improved baggage handling, less walking between terminals, greater coordination of connecting flights, and better handling of passengers in case of flight delays.

136. See Collis, supra note 117 (noting corresponding conveniences made possible by codesharing arrangements). Other costs include greater risks of missing connections and of lost baggage.

137. Although such transfers are rare today, they were more common prior to deregulation. See Borenstein, supra note 86 , at 50 . Although some of the later decreases are due to market concentration following mergers among major carriers, Borenstein argues that "the earlier and more significant declines are explained largely by formation of hub-and-spoke systems." Id.

138. Using Bork's distinction between natural and artificial barriers to entry, such costs would be natural barriers to entry and thus not the primary concern of antitrust regulation. Artificial barriers, in Bork's lexicon, are "barriers that are not forms of superior efficiency and which yet prevent the forces of the market-entry or the growth of smaller firms already within 
connecting flights may be in entirely different terminals, causing travelers making off-line connections to spend a significant amount of additional time and effort to reach their connecting gates. ${ }^{139}$ However, if the proliferation of code-sharing agreements is any indication, achieving logistical compatibility ${ }^{140}$ among all airlines may not be prohibitively costly.

In addition to logistical incompatibilities, legacy airlines exhibit discriminatory interconnection-pricing structures. Empirical studies demonstrate that hub-and-spoke airlines charge a "hub premium" for flights originating or terminating at a hub airport, meaning that fares on such flights are significantly higher than on flights that originate or terminate at a nonhub airport. ${ }^{141}$ This effect is observed even "while controlling for traffic volume, business/tourist mix, the number of plane changes a passenger must make, ... concentration and market share on specific routes, airportspecific congestion, and many other factors." ${ }^{142}$ Notably, however, hub premiums are not charged to passengers who pass through hubs while making intra-airline connections. ${ }^{143}$

It is possible to infer from this data that behavior in the airline industry conforms to the airline interconnection model discussed above. Hub premiums have often been explained as an effect of the market power produced by a dominant airline's overwhelming presence at its hub airport. ${ }^{144}$ But applying Economides's interconnection-pricing model to the airine market suggests that hub premiums may also be a cause of legacy airlines' dominance. Hub premiums function as discriminatory interconnection fees. Dominant airlines charge higher prices for individual

the industry - from operating to erode market positions not based on efficiency." BORK, supra note 49 , at 311 .

139. However, information such as the walking distance between different airlines' terminals could be easily provided to travel agents and consumers buying over the Internet. Popular websites such as Orbitz already provide information such as the make and model of the aircraft scheduled for each flight; presumably, it would be relatively easy for them to incorporate other useful information. See Orbitz, http://www.orbitz.com (last visited Oct. 17, 2004).

140. "Logistical compatibility" means elimination of avoidable logistical costs involved in off-line transfers. Such compatibility would require every airline (1) to allow every other airline to access its computer network so the originating airline could check in passengers making an offline connection and (2) to pass connecting passengers' bags on to their connecting carriers' baggage-handling systems.

141. See Borenstein, supra note 86 , at 54-56. Borenstein finds that where an airline dominates its hub, it tends to charge higher prices than it does throughout the rest of its system, and he observes that cost differences do not explain this phenomenon. Notably, airlines charge more at their hubs than other major carriers with less significant operations at those airports. See also GAO, AIRLINE COMPETITION: HIGHER FARES AND LESS COMPETITION CONTINUE AT CONCENTRATED AIRPORTS (1993), available at http://archive.gao.gov/t2pbat5/149695.pdf (finding that fares per mile flown on routes with endpoints at concentrated hub airports were twenty-two percent higher than fares on other routes).

i42. Borenstein, supra note 86 , at 56.

143. See id.

144. See id. at 55-56. 
flights to and from a hub than the implicit internal price of such flights when sold as part of an intra-network itinerary. Because individual flights to and from a hub afford the opportunity to make inter-network connections, hub premiums make inter-network itineraries more costly than intra-network itineraries. As a result, small entrant firms are excluded from the connecting passenger market, and hub airports tend toward concentration. ${ }^{145}$

Interconnection pricing in the airline industry is more complex than in the telecom industry because unlike calls, some passengers ("hub passengers") may terminate at the hub rather than merely pass through to a connecting city. Since airlines cannot readily distinguish between hub passengers and inter-network connecting passengers, pricing decisions for flights to and from hubs will necessarily apply to both sets of passengers. Thus, a dominant network that sets high interconnection prices might be expected to lose market share to entrants who compete for hub passengers.

Dominant airlines therefore must weigh the strategic benefits of high interconnection fees against their pricing strategy for hub passengers. However, discriminatory interconnection pricing creates a feedback effect that tends to ameliorate this tension. Because the market for connecting passengers constitutes a major portion of the air travel market, ${ }^{146}$ capturing all or nearly all connecting travel allows an airline to dominate a hub such that many routes are near-monopolies. Entrants that are excluded from the connecting market may not be able to achieve optimal load factors; this reduces their cost-per-passenger advantage over the dominant airlines. Thus, dominant airlines engaging in discriminatory interconnection pricing may lose market share on passengers whose destination is the hub, but the pricing strategy reduces this effect by raising rivals' costs. ${ }^{147}$

As Economides's model predicts and observation of the airline industry appears to confirm, the dominant carriers' interconnection pricing ensures that intra-network travel is cheaper than inter-network travel. ${ }^{148}$ The effect of this pricing regime in the airline industry is to "tip" travelers using a

145. Cf. Economides et al., supra note 39, at 1022.

146. In 1990, fifty-two percent of all domestic trips over 1500 miles and thirty-eight percent of all domestic trips between 500 and 1500 miles involved a flight change. See Borenstein, supra note 86 , at 49 .

147. Exclusion of rivals from the market for connecting passengers also has deleterious effects on smaller rivals' ability to compete for hub passengers. As Michael Levine notes,

Except in relatively large markets, nonstop service between cities will typically be offered only by airlines which operate hubs at one end or the other. Only these can combine local market passengers with connecting passengers to get enough traffic to enough departures to provide a competitive choice of nonstop flights in the market. Levine, supra note 85 , at 443 .

148. For passengers who check their luggage, the logistical costs of interairline transfers may be sufficient to prevent inter-network travel. However, for passengers who carry their luggage with them, or for those who are very insensitive to time costs but very sensitive to price, the logistical costs without discriminatory interconnection pricing would not bar interairline transfers. 
multi-leg travel itinerary toward intra-network itineraries. Put another way, dominant airlines' pricing strategies in the market for connecting travel permit competition only at the system (full-itinerary) level, foreclosing competition at the individual flight level.

Thus, logistical incompatibilities and interconnection pricing together tend to eliminate inter-network air travel and exclude entrants from the market for connecting passengers. But such incompatibilities are not necessarily inefficient. As Part II discussed, incompatibilities, even if they produce an allocative-efficiency loss by preserving some level of market power, are nevertheless desirable when they are necessary to achieving greater productive efficiencies. Thus, the question addressed in Part IV is whether, as in Aspen Skiing, this interconnection-pricing strategy harms consumer welfare.

\section{ASSESSING EFFICIENCY, PROPOSING REFORM}

Not every instance of incompatibility is a market failure. ${ }^{149}$ Moreover, as the Court recently noted in Verizon Communications $v$. Law Offices of Curtis V. Trinko, not every theoretical market failure can or should be remedied. ${ }^{150}$ As Part II established, the efficiency of compatibility decisions must be evaluated against a standard baseline. Although courts ${ }^{151}$ and scholars $^{152}$ often look at the way the market functioned prior to the challenged conduct as a baseline for comparison, ${ }^{153}$ such an undertaking is problematic in the airline industry because of its fairly recent emergence from regulation. Here, the challenged conduct-charging high interconnection rates, or hub premiums-became prominent shortly after deregulation, but the regulated market prior to the challenged conduct hardly displayed optimal distribution patterns. ${ }^{154}$ It is therefore appropriate to assess the efficiency of the market under an incompatibility regime by considering the merits of an alternative state of affairs that might exist under a compatible one. ${ }^{155}$

This Part employs the analytical framework set out in Part II to assess whether the incompatibilities identified in Part III are suboptimal. Section A draws on network-compatibility theory to propose a regulatory regime that would achieve logistical compatibility and nondiscriminatory

149. See supra notes $49-50$ and accompanying text.

150. 124 S. Ct. 872,883 (2004).

151. See, e.g., Aspen Skiing Co. v. Aspen Highlands Skiing Corp., 472 U.S. 585, 604 (1985) ("Ski Co.'s decision to terminate the all-Aspen ticket was thus a decision by a monopolist to make an important change in the character of the market.").

152. See, e.g., BORK, supra note 49 , at 156.

153. See id. passim.

154. See, e.g., Keeler, supra note 1, at 421 (finding that, in 1968, regulated fares were twenty to ninety-five percent higher than unregulated fares).

155. See supra text accompanying notes $60-61$. 
interconnection pricing among airlines. Section B compares the welfare effects of the proposed regulations with the status quo.

\section{A. Compatibility Through Regulation}

Solving the problem of logistical incompatibility is straightforward. Every airline could be required to cooperate with every other in the following ways: First, airlines must link their computer systems to the extent necessary to allow an originating airline to check inter-network passengers through to their final destination. ${ }^{156}$ Second, airlines on which inter-network passengers originate must pass checked bags on to the connecting airline, thus eliminating the need to reclaim and recheck baggage in order to make an inter-network connection. These two requirements would serve to remove the most significant "artificial" logistical barriers to airline interconnection, though some "natural" barriers may remain. ${ }^{157}$

Eliminating discriminatory interconnection pricing requires a more complex solution. Applying Economides's analysis to the airline industry suggests two primary methods for regulating interconnection pricing: (1) imposing a condition of reciprocity, under which all firms are required to charge the same rate for the same services; and (2) imposing an imputation constraint on pricing, under which each firm must provide its component flights to inter-network connecting passengers at the same price it charges its own intra-network connecting passengers. ${ }^{158}$

In the airline industry, reciprocity pricing is the less useful of the two strategies. The regulator must somehow arrive at the reciprocal priceeither by simply imposing a price on the market or by allowing the parties to negotiate. ${ }^{159}$ Price setting by regulators is almost always a poor option, as years of airline regulation have taught us. ${ }^{160}$ Setting the reciprocal price through negotiations among airlines is a better option, but, unlike the telecom industry, where the cost of completing calls is virtually homogeneous, in the airline industry, fares across routes are heterogeneous because each route presents different costs and differing degrees of market power by each firm. Negotiations, therefore, would be arduous and

156. Airlines that code share already reciprocally perform these same functions, so it would not be logistically infeasible in at least some circumstances. See, e.g., United and US Airways Code Share FAQ, http://www.united.com/page/article/0,6722,50041,00,00.html\#3 (last visited Oct. 17, 2004) ("'C]oordination of each company's computer systems will improve efficiency by allowing the use of e-tickets, issuance of connecting boarding passes and automated bag-tag issuance.").

157. See BORK, supra note 49 , at 311 ; see also supra notes $138-140$ (noting barriers that inhere in the industry).

158. See Economides et al., supra note 39, at 1015.

159. See id. at 1022.

160. See, e.g., Keeler, supra note 1, at 421-23. 
complex, and since dominant firms would retain the incentive to thwart interconnection, they would likely push for very high reciprocal interconnection fees. Moreover, as firms entered and exited the market, the balance of power would shift and renegotiation would be necessary. In short, the negotiation process would be a drain on resources but would not eliminate the possibility of intra-network pricing advantages.

Imputation, by contrast, would require more limited regulatory involvement and resources. An imputation rule requires that prices for individual flights be no higher than the implicit price for such flights when sold as part of a full intra-network itinerary. ${ }^{161}$ But under the legacy airlines' current pricing policies, there is no single implicit internal price for each component flight. Each component flight may form part of dozens of connecting itineraries, and for each itinerary there may be a different implicit price charged to intra-network connecting passengers. Moreover, the airlines do not specify what portion of the price of a multiflight itinerary is attributable to each component flight. This is problematic because in order to impute the internal price of component flights to inter-network travelers, the internal price must be determinate. Therefore, before an imputation rule may be imposed, airlines must be required to price and sell their flights individually, rather than bundled in an itinerary. This would force airlines to identify the price that intra-network connecting passengers pay for each component flight, though it would also require airlines to depart from their current pricing practices by setting a single internal price for each component flight.

Once airlines have identified the internal price of component flights, the imputation constraint requires a network to charge inter-network consuiners the same price for each component as it charges its intra-network consumers. This rule would prohibit airlines from lowering the internal price of connecting flights by offering discounts on component flights to intra-network connecting passengers only. As a result, a passenger who purchases two tickets for a connecting itinerary separately would pay the same price as one who purchased the tickets as a complete itinerary.

Granted, imposing an imputation constraint would require some airlines to make significant changes in their pricing structure. Yet airlines could still market and sell complete itineraries, so long as the itinerary price reflected the sum of the component flights' unbundled prices. And airlines would still be free to price fares as high or low as they chose, and to price discriminate among passengers by means of purchasing restrictions, heterogeneous seat classes, and so on. ${ }^{162}$ Thus, such a regulatory regime would be far less invasive than direct price regulation, because imputation

161. See Economides et al., supra note 39, at 1024.

162. See Michael E. Levine, Price Discrimination Without Market Power, 19 YALE J. ON REG. 1 (2002) (arguing that price discrimination is necessary fur airlines to cover their common costs). 
merely requires that component flights be available to inter-network passengers at the same price charged to intra-network passengers. ${ }^{163}$

The enforcement mechanism could be a department within the Federal Aviation Administration or a stand-alone agency. Monitoring compliance could be left to the market because firms would have strong incentives to detect and report competitors' discriminatory interconnection pricing. The regulatory body's main task would be to administer a process for adjudicating claims against firms that violated the imputation rule. Remedies for violations might include disgorgement of improperly acquired fares as well as attorney's fees.

\section{B. Welfare Analysis}

Regulation must always be undertaken cautiously. The central question is whether the regulation will achieve benefits that outweigh any costs it causes. That is, will regulation produce a net welfare gain or loss?

The most obvious effect of the imputation requirement would be the elimination of hub premiums. Since passengers on one-stop routes between nonhub cities usually choose between substitute itineraries through different hubs, major airlines would be forced to price their individual flight fares competitively. Any attempt to raise the price of interconnecting by charging a hub premium would be unavailing because the dominant airline would have to raise fares on its own connecting passengers as well.

Data cited in a recent antitrust decision in the Tenth Circuit demonstrate that when low-cost carriers began competing with American Airlines on flights from Wichita to Dallas (an American Airlines hub), prices fell ${ }^{164}$ and the average number of passengers per month on the route doubled, ${ }^{165}$ revealing a significant deadweight loss from American's hub-premium pricing. ${ }^{166}$ The proposed regulations would encourage entry on spoke routes and lead to competitive pricing that would eliminate such allocative inefficiencies. ${ }^{167}$

163. Nothing here should be construed as attacking or criticizing the practice of price discrimination by airlines. The price of an airline seat varies widely depending on date of purchase, use restrictions, service class, etc. All such pricing strategies could continue unhampered, within the bounds of imputation. Frequent flier miles, which are simply a rebate scheme, would be allowed so long as on-line connectors were awarded the same number of miles as off-line connectors.

164. Average fares in the pre-"predation" period ranged from $\$ 99$ to $\$ 108$ but dropped to $\$ 58$ to $\$ 102$ in the first two-and-a-half years during which American faced competition from several low-cost carriers. United States v. AMR Corp., 335 F.3d 1109, 1112 n.4 (10th Cir. 2003).

165. Average monthly passengers in the pre-"predation" period ranged from 3932 to 5557 but jumped to reach 10,076 to 11,041 in the period during which American allegedly engaged in predatory pricing. Id.

166. See ANDREW Gavil et al., ANTITRUSt LAW IN PERSPECTIVE: CASES, ConCEPTS, AND PROBLEMS IN COMPETITION POLICY 27 (2002).

167. See BORK, supra note 49 , at 91 . 
Furthermore, the proposed regulations would achieve additional productive efficiencies by allowing more efficient entrants into the market serving connecting passengers. ${ }^{168}$ Small, efficient carriers are now effectively barred from providing one leg of a connecting itinerary because of the logistical costs of interfirm connections and the pecuniary barrier of discriminatory interconnection pricing. With both of those barriers removed, the most efficient firm would provide each component flight, resulting in an overall improvement in the allocative and productive efficiency of the industry.

In addition to lower prices for air travel, increased productive efficiency would increase the value of the air transport network as a whole. The air transport network exhibits indirect network effects. An individual who uses the air transport network benefits from an increase in the number of other users insofar as increased air travel makes more destinations accessible with greater frequency. ${ }^{169}$ At lower prices, more consumers would choose air travel, which means that more routes would be served and with greater frequency. This expansion both of the size of the network and the density of its service would represent an increase in the indirect network benefits that redound to all air travelers. ${ }^{170}$

Another relevant inquiry is the effect of the proposed regulation on efficiencies created by the hub-and-spoke system. The hub-and-spoke system combines passengers with diverse destinations on flights into the hub, which creates sufficiently high load factors on the route to allow frequent jet service in many city-pair markets whose traffic density would otherwise not support it. Also, by combining nonstop passengers with connecting passengers, hubbing allows higher load factors on flights to and from the hub. ${ }^{171}$ The efficiency of the hub-and-spoke structure allows onestop connecting service between a wide range of cities. ${ }^{172}$

Hub-and-spoke airlines would, under the proposed regulation, still be free to operate their hubs and capture the efficiencies of such a network structure. However, because the regulations would allow greater entry into the market for connecting passengers and would allow for inter-network connections, each hub-and-spoke network would transform from a singlefirm network to a multifirm network. But such networks would not have the benefit of centralized route coordination. Currently, a hub-and-spoke airline chooses a location at which to form a hub and routes its connecting flights

168. See Levine, supra note 85 , at 443.

169. See the discussion of indirect network benefits supra Section I.A.

170. See supra notes $9-13$ and accompanying text.

171. See Levine, supra note 85 , at $441-43$.

172. See id. However, as Levine notes and numerous economists have demonstrated, see supra note 103, adopting a hub-and-spoke system is also an effective method of entry deterrence. This should at least give us pause to consider whether airlines adopted the hub-and-spoke system purely to achieve productive efficiencies or whether deterring entry was an additional motivation. 
through that airport. A multifirm hub-and-spoke network would instead form de facto hubs - airports at which high numbers of flights converge, presenting passengers with a wide selection of connecting flights. Such a network should duplicate the primary efficiencies of single-firm hubbing, namely higher load factors and greater flight frequency to and from nonhub cities. ${ }^{173}$ The same qualities that led legacy airlines to establish hubs in their present locations will make those locations desirable as de facto hubs in a multifirm network. Hubs have developed mostly at large, centrally located population centers like Chicago, Cincinnati, Denver, and Atlanta that draw a great deal of direct traffic to and from a wide range of secondary cities. Even without coordination among firms, large population centers would still offer connecting passengers the widest range of connecting destinations because airlines would still fly many flights in and out of such de facto hubs. Therefore, a multifirm hub-and-spoke network will capture many, if not all, of the productive efficiencies a single-firm hub-and-spoke network offers.

There are some efficiencies that a de facto hub may not duplicate perfectly. Examples might include connecting-flight coordination ${ }^{174}$ and delay/cancellation management. ${ }^{175}$ Yet, to the extent that such intrafirm efficiencies are highly valued by consumers, larger networks that can achieve such efficiencies would rightly succeed in the market, because consumers would prefer intrafirm itineraries even without discriminatory interconnection pricing. Other airlines would either duplicate these efficiencies or lose market share. ${ }^{176}$ But because the proposed regulations would not undermine such intrafirm efficiencies, ${ }^{177}$ the welfare effects of the regulations are neutral in this regard.

Against the efficiency gains expected under the proposed regulations, we must weigh the costs of achieving regulatory compliance. Such costs wou'd include interconnecting the airlines' computer systems,

173. See Borenstein, supra note 86 , at 50 .

174. Hub-and-spoke airlines typically operate in waves, in which many incoming flights land in close temporal proximity, and then, after a delay sufficient to allow passengers to make their connections, many outgoing flights take off in close succession. This strategy is meant to minimize most passengers' layover time, although it also contributes to severe congestion at peak hours. See Melvin A. Brenner, Airline Deregulation-a Case Study in Public Policy Failure, 16 TRANSP. L.J. 179, 213 (1988).

175. When passengers traveling on an intra-network itinerary miss their connecting flights because of a delay on the flight into the hub, the network firm typically transfers them to the next flight at no extra charge. But if those traveling on an inter-network itinerary miss their connecting flights, they may face additional fees because the connecting airline was not responsible for their delay.

176. For instance, smaller airlines may have to relax restrictions or penalties for passengers who miss connections. Southwest already has a policy of no-fee ticket changes. See Sw. Airlines, Customer Service Commitment 5 (Nov. 14, 2003), available at http://www.southwest.com/ about_swa/customer_service_commitment/customer.pdf.

177. Compatibility would not hamper firms' ability to schedule their flights to land and take off in waves that make flight connections convenient. 
reconfiguring baggage systems to make the necessary interairline transfers, and monitoring firms' compliance with imputation pricing. Some of these costs, namely linking computers and reconfiguring baggage handling systems, might be significant. On the other hand, implementing and monitoring imputation pricing would pose few special problems-fares are published and competitors could, for the most part, monitor one another's compliance, filing a complaint when discriminatory pricing was observed. The cost of assuring compliance, while not trivial, should nevertheless be relatively slight.

It appears that few productive efficiencies depend upon the current regime of incompatibility among airline networks, while the inefficiencies caused by incompatibility are manifest. The proposed regulations will produce a network comprising all airline firms, which will replicate the most important efficiencies of the single-firm hub-and-spoke system. And while the proposed regulations would not be costless, the allocative and productive efficiencies gained through a system of robust competition for connecting passengers suggest that the concept is worthy of further consideration.

The legacy airlines' eroding market share and staggering recent losses raise the possibility that the proposed regulations are a cure in search of a disease. ${ }^{178}$ But the proposed regulations merit our attention for two reasons. First, in the words of Robert Bork, "Antitrust is valuable because in some cases it can achieve results more rapidly than can market forces. We need not suffer losses while waiting for the market to erode cartels and monopolistic mergers."179 The point applies equally to the competitionenhancing reforms proposed here. To the extent that incompatibility protects inefficient airline firms from competition from small, efficient entrants, every day that logistical incompatibilities and discriminatory interconnection fees persist represents another day of inefficiency. If we can immediately achieve efficiencies that might take ten or fifteen years to develop in the market, then regulation may be the better alternative.

Second, and more importantly, this proposed regulatory scheme is not an attack on legacy carriers as such, nor is it necessarily intended to deconcentrate the industry or unseat the current market leaders. It is simply

178. Delta reported a net loss of $\$ 1.96$ billion for the second quarter of 2004. See Press Release, Delta Air Lines, Delta Air Lines Reports June 2004 Quarter Results (July 19, 2004), available at http://news.delta.com/article_display.cfm?article_id=9367. United reported a net loss of $\$ 247$ million for that period, see Press Release, United, UAL Corporation Reports SecondQuarter Restructuring Progress, Says More Work Needed (July 29, 2004), available at http://www.united.com/press/detail/0,6862,52167,00.html, and Continental, a net loss of $\$ 17$ million, see Update 1: Continental Airlines Posts Loss in 2Q, ASsOCIATED PRESS, July 20, 2004, available at http://www.forbes.com/feeds/ap/2004/07/20/ap 1460782.html. American, however, reported a net profit of $\$ 6$ million for the second quarter of 2004. See Keith L. Alexander, American Posts Profit in Difficult Second Quarter, WASH. POST, July 22, 2004, at E2.

179. BORK, supra note 49 , at 311 . 
an attempt to ensure that success in the airline industry comes through "competition on the merits." "180 The fact that dominant networks' private incentives favoring incompatibility diverge from public incentives to achieve compatibility is not unique to legacy airlines; any dominant firm will face the same incentive to discriminate in interconnection pricing. In time, today's low-cost carriers may unseat the legacy airlines and become dominant themselves. Imputation pricing and logistical compatibility among airline networks would assure that an airline's dominance is only as durable as its superior productive efficiency.

\section{CONCLUSION}

This Note has attempted to employ network-compatibility theory to shed new light on the behavior of network airlines, with the purpose of refining our understanding of consumer welfare in the airline industry. In particular, I have argued that both as a theoretical matter and as an observed phenomenon, competition in the airline industry is functioning at a suboptimal level, in part because of incompatibilities that restrict competition to the network level and foreclose it at the component level. Dominant airline networks have incentives to set high interconnection fees that reduce total network value and exclude entrants from the connecting market. Likewise, logistical incompatibilities have thwarted compatibility among airline networks, further harming consumer welfare by reducing network benefits and preventing competition for component flights.

As Parts III and IV discussed, the empirical evidence shows at least the potential for increasing consumer welfare through carefully limited regulatory strategies. I hope this Note will stimulate further theoretical and, especially, empirical study of how airline networks qua networks make compatibility and interconnection decisions, which in turn may prompt a regulatory effort of the sort I suggest.

Some airlines may object to the proposed regulations, claiming that unilateral action is the hallmark of competition or that firms should be allowed to reap the benefits of their investments in hub-and-spoke networks with broad scope. ${ }^{181}$ But network-compatibility theory demonstrates that unfettered competition in network industries may produce suboptimal equilibria. Moreover, unilateralism and competition are not themselves the primary concern of antitrust; they are merely proxies for consumer welfare. We preserve competition because, in most cases, competition maximizes consumer welfare. Individual competitors do not and should not have a right to act in ways that harm consumer welfare, appeals to "fairness"

180. Aspen Skiing Co. v. Aspen Highlands Skiing Corp., 472 U.S. 585, 605 n.32 (1985) (internal quotation marks omitted).

181. See, e.g., Brief of Amicus Curiae American Airlines at 2, Aspen Skiing (No. 84-510). 
notwithstanding. ${ }^{182}$ Thus, unilateral competition is valuable as a default proxy for welfare maximization only when the basis of competition is superior efficiency rather than exclusionary tactics. ${ }^{183}$

Finally, as Part IV emphasized, the incentive for dominant firms to create artificial logistical incompatibilities and engage in discriminatory interconnection pricing will continue even after the demise of today's dominant airlines. The reforms proposed here will be as important for maintaining efficiency in a future market dominated by the low-cost carriers of today as they are in the current market, because they merely ensure that dominant carriers become dominant through superior efficiency and only remain dominant so long as their efficiency advantage persists. 


$$
* * *
$$

